\title{
Resistance of Closely Mown Fine Fescue and Bentgrass Species to Snow Mold Pathogens
}

Jeff Gregos, former Research Assistant, Department of Plant Pathology, University of Wisconsin-Madison 53706; M. D. Casler, United States Department of Agriculture-Agricultural Research Service, U.S. Dairy Forage Research Center, Madison, WI 53706-1108; and J. C. Stier, Professor, Department of Horticulture, University of Wisconsin-Madison

\begin{abstract}
Gregos, J., Casler, M. D., and Stier, J. C. 2011. Resistance of closely mown fine fescue and bentgrass species to snow mold pathogens. Plant Dis. 95:847-852.

Creeping bentgrass (Agrostis stolonifera) is the primary species used on golf courses in temperate regions but requires prophylactic fungicide treatment to prevent snow mold diseases. We hypothesized that fine fescues (Festuca spp.) and colonial bentgrass (A. capillaris) have superior resistance to snow mold diseases compared with creeping bentgrass. Our objective was to compare the resistance of fine fescues, colonial bentgrass, and creeping bentgrass to snow mold diseases caused by Microdochium nivale and Typhula spp. Field plots were established in two separate years on fairways of three golf courses in Wisconsin to encompass the geographic distribution of snow mold

pathogens. The experimental design was a split-split-split plot arrangement with three replications. Whole plots were pathogen species, host genus were subplots, host cultivars were sub-subplots, and inoculated versus noninoculated treatments were sub-sub-subplots. Plots were visually evaluated each spring for disease, turf quality, and Pоа апnиa infestation. Data were analyzed using planned contrasts. Inoculation effects depended on pathogen type and location. Creeping bentgrass always had the most snow mold damage. Fine fescues had less snow mold damage than colonial bentgrass except for one year-location but did not provide acceptable year-long turf quality due to $P$. аппиа invasion.
\end{abstract}

Several snow mold pathogens are known to damage amenity turfgrasses, most commonly Microdochium and Typhula spp. (3,79). Microdochium nivale (Fr.) Samuels \& I.C. Hallett is the causal agent of Microdochium patch and has the broadest range of temperature adaptation of the snow mold pathogens, capable of causing disease with or without snow cover $(13,17)$. Gray snow mold is caused by Typhula incarnata Lasch and T. ishikariensis $\mathrm{S}$. Imai is the causal agent of speckled snow mold; of the two, T. ishikariensis is usually considered the most aggressive (10). In Wisconsin, T. incarnata is the dominant Typhula sp. in the southern part of the state. T. ishikariensis is favored by longer periods of snow cover and lower temperatures than $T$. incarnata and, consequently, occurs primarily in the northern part of the state $(8,10,14)$. T. phacorrhiza develops under conditions similar to those for $T$. ishikariensis $(8,14,21)$. Previous research indicated some $T$. phacorrhiza isolates act as a biocontrol of $M$. nivale and other Typhula spp. snow mold pathogens $(5,9,10)$. Isolation of $T$. phacorrhiza from northern Wisconsin golf courses in the late 1990s suggested that the fungus may also act as a pathogen (14).

Creeping bentgrass (Agrostis stolonifera L.) and annual bluegrass (Poa annua L.) compose the vast majority of golf course fairway turf in Canada and the northern United. Both species are highly susceptible to damage by various snow mold diseases, often requiring fungicide treatments to survive snow mold infestations (2). Usually considered to be a weed, annual bluegrass is rarely planted intentionally but its ability to regenerate from soil seed banks as turf is killed by snow mold or other stresses allows $P$. аппиа to dominate many closely mown turf areas over time (4). Unless preventive fungicides are applied in late autumn, the severe turf damage from snow molds during winter will delay opening of golf courses in the spring until new grass develops, usually $P$. annua, resulting in significant revenue loss.

Corresponding author: J. Stier, E-mail: jstier@wisc.edu

Accepted for publication 11 March 2011.

doi:10.1094/PDIS-11-10-0791

(C) 2011 The American Phytopathological Society
Increasing restrictions on fungicide usage for amenity grasses may someday require other means for avoiding snow mold damage. Additionally, concerns regarding water use and even fertilizer requirements are compelling turf managers and breeders to seek lower-maintenance grasses. Resistant grass varieties may provide all or part of the solution for reducing dependence on fungicides to prevent snow mold damage. Empirical evidence indicates that germplasm of current creeping bentgrass cultivars is not sufficiently resistant to eliminate fungicide treatments. Fine fescues (Festuca spp.) are often touted for their low maintenance requirements compared with other cool-season turfgrasses. In Norway, Aamlid et al. (1) concluded that Chewings (Festuca rubra subsp. commutata) and slender creeping red fescues (F. rubra subsp. trichophylla) were better suited than bentgrasses for low-maintenance golf course situations where no fungicides were applied, in part because they had less winter damage from snow molds and abiotic stress than bentgrasses. Colonial bentgrass (A. capillaris) is purportedly less susceptible to diseases such as pink snow mold than creeping bentgrass, has lower maintenance requirements, and is suited for the mowing heights typical of fairways (2). Neither Festuca spp. nor colonial bentgrass have been compared with creeping bentgrass in situ for their relative resistance to snow mold pathogens.

We hypothesized that snow mold resistance would be greatest in fine fescues, followed by colonial bentgrass and then creeping bentgrass. Our objective was to compare the inherent resistances of colonial bentgrass, creeping bentgrass, and fine fescue species to snow mold diseases.

\section{Materials and Methods}

Turf production and maintenance. Field plots were established in June 1998 and 1999 at three locations: Gateway Golf Club, Land O' Lakes, WI; SentryWorld Golf Club, Stevens Point, WI; and O. J. Noer Turfgrass Research and Educational Facility, Verona, WI. Gateway Golf Club and other golf courses in the area had a history of snow mold diseases caused by M. nivale, T. ishikariensis, and T. incarnata; T. phacorrhiza was also occasionally found in disease patches (14). SentryWorld Golf Club and other golf courses in central Wisconsin had a history of snow mold diseases caused primarily by $M$. nivale and $T$. incarnata, with a lesser 
degree of T. ishikariensis. The O. J. Noer Turfgrass facility had a history of snow mold disease primarily caused by $M$. nivale and occasionally by $T$. incarnata. Glyphosate (RoundupPro; Monsanto Corporation, St. Louis) was applied using a backpack sprayer to eradicate existing vegetation. Till cultivation was used to prepare the plots and fine grading was done with landscape rakes in 1998. In 1999, the plots were first stripped of vegetation using a sod cutter, then till cultivated. Dazomet (BasamidG; Certis USA, LLC, Columbia, MD) was applied prior to seeding at a rate of $396 \mathrm{~kg} \mathrm{ha}^{-1}$ and irrigated with $1.27 \mathrm{~cm}$ of water to help develop a crust on the soil. The purpose was to reduce $P$. апnua seed germination during the recovery period the following spring. The soil was scarified with a sand-trap cultivator 10 days after the dazomet application.

Plots were arranged in a randomized complete block design with three replicates at each experiment (six location-year combinations). Randomization was restricted to a split-split-split plot arrangement, with pathogen species as whole plot, host genus as the subplots, host cultivar as sub-subplot, and inoculated versus noninoculated as sub-sub-subplot. Inoculation was chosen as the last split (paired plots) to allow maximum precision for this comparison, given the presence of natural inoculum that would introduce spatial variability to this comparison in a non-paired-plot design. Each sub-sub-subplot measured $1.47 \mathrm{~m}^{2}$. The species and cultivars evaluated were A. stolonifera ('Cato', 'Penncross', 'Penneagle', 'Seaside II', and 'SR1119'), A. capillaris ('Astoria', 'SR 7100', 'Tiger', and 'Tendez' in 1998 or 'Bardot' in 1999), A. castellana ('Highland'), F. rubra ('Dawson', 'Pennlawn', and 'Jasper'), and
F. rubra subsp. commutata ('SR 5100', 'Tiffany', and 'Victory'). Cultivars were chosen because they represented readily available commercial cultivars. Agrostis spp. were broadcast seeded at a rate of $74.2 \mathrm{~kg} \mathrm{ha}^{-1}$ and Festuca spp. at a rate of $180.0 \mathrm{~kg} \mathrm{ha}^{-1}$.

The plots were maintained as golf course fairways with a mowing height of $12.7 \mathrm{~mm}$ in Verona and Stevens Point and $19 \mathrm{~mm}$ in Land O' Lakes. The plots received $\mathrm{P}$ at $21.7 \mathrm{~kg} \mathrm{ha}^{-1}$ from a starter fertilizer (15-24-8; Spring Valley, Jackson, WI) and N at $27.7 \mathrm{~kg}$ $\mathrm{ha}^{-1}$ from urea (46-0-0) applications at 3-week intervals for 9 weeks. After establishment, the plots received $\mathrm{N}$ at $148.2 \mathrm{~kg} \mathrm{ha}^{-1}$ from a general turf fertilizer (21-3-12; Spring Valley) applied in three equal allotments in May, July, and October.

Inoculum preparation and inoculation. Isolates used in this study were obtained from various golf courses within Wisconsin during spring 1997. M. nivale (GW 97.1) was isolated from Land O' Lakes golf course. T. incarnata (3.279), T. ishikariensis (2.105BX), and T. phacorrhiza (3.120B) were obtained from golf course turf in Hurley, Stevens Point, and Woodruff, WI, respectively. Fungi were isolated by plating diseased turfgrass foliage onto potato dextrose agar (PDA; Difco Laboratories, Detroit) amended with chloramphenicol to obtain $M$. nivale. Typhula spp. were obtained by plating single sclerotia onto the same media. Prior to plating, foliage was surface disinfested by soaking in a $10 \%$ bleach solution for $5 \mathrm{~min}$ followed by double rinsing with sterilized distilled water, then blotted dry onto sterile filter paper. Sclerotia were prepared for plating by soaking in sterile distilled water for $2 \mathrm{~min}$, rinsing with sterile distilled water, and soaking in

Table 1. Mean squares (MS), $P$ values, and percentage of sum of squares $(\% \mathrm{SS})$ for all treatment effects and treatment-location interactions determined for snow mold damage on creeping bentgrass, colonial bentgrass, Chewing's fescue, and red fescue cultivars evaluated at five locations (L) in 1999 and 2000

\begin{tabular}{|c|c|c|c|c|}
\hline Source & df & MS & $P$ value & $\% \mathrm{SS}$ \\
\hline Inoculation (I) & 1 & 45,557 & $<0.0001$ & 5.9 \\
\hline Microdochium vs. Typhula spp. (MT) & 1 & 39,805 & 0.0005 & 5.2 \\
\hline Typhula incarnata vs. other (TT) & 1 & 302 & 0.7260 & 0.0 \\
\hline T. ishikariensis vs. T. phacorrhiza (IP) & 1 & 16,126 & 0.0166 & 2.1 \\
\hline $\mathrm{I} \times \mathrm{MT}$ & 1 & 14,017 & $<0.0001$ & 1.8 \\
\hline $\mathrm{I} \times \mathrm{TT}$ & 1 & 4332 & $<0.0001$ & 0.6 \\
\hline $\mathrm{I} \times \mathrm{IP}$ & 1 & 21,375 & $<0.0001$ & 2.8 \\
\hline I and isolates subtotal & 7 & $\ldots$ & $\ldots$ & 18.3 \\
\hline $\mathrm{L} \times \mathrm{I}$ & 4 & 4,593 & $<0.0001$ & 2.4 \\
\hline $\mathrm{L} \times \mathrm{MT}$ & 4 & 1,536 & 0.6397 & 0.8 \\
\hline $\mathrm{L} \times \mathrm{TT}$ & 3 & 7,285 & 0.0507 & 2.8 \\
\hline $\mathrm{L} \times \mathrm{IP}$ & 1 & 82 & 0.8554 & 0.0 \\
\hline $\mathrm{L} \times \mathrm{I} \times \mathrm{MT}$ & 4 & 1,465 & $<0.0001$ & 0.8 \\
\hline $\mathrm{L} \times \mathrm{I} \times \mathrm{TT}$ & 3 & 1,666 & $<0.0001$ & 0.6 \\
\hline $\mathrm{L} \times \mathrm{I} \times \mathrm{IP}$ & 1 & 31 & 0.5983 & 0.0 \\
\hline $\mathrm{L} \times \mathrm{I}$ and isolates subtotal & 20 & & & 7.4 \\
\hline Bent vs. fescue (G) & 1 & 175,646 & $<0.0001$ & 22.8 \\
\hline Creeping vs. colonial (CC) & 1 & 94,132 & $<0.0001$ & 12.2 \\
\hline Chewing's vs. red fescue (FF) & 1 & 574 & 0.1388 & 0.1 \\
\hline Cultivars/groups (Cult) & 12 & 1,572 & $<0.0001$ & 2.4 \\
\hline Species and Cult subtotal & 15 & & & 37.5 \\
\hline $\mathrm{L} \times \mathrm{G}$ & 4 & 14,168 & $<0.0001$ & 7.3 \\
\hline $\mathrm{L} \times \mathrm{CC}$ & 4 & 8,922 & $<0.0001$ & 4.6 \\
\hline $\mathrm{L} \times \mathrm{FF}$ & 4 & 117 & 0.7741 & 0.1 \\
\hline $\mathrm{L} \times$ Cult & 46 & 967 & $<0.0001$ & 5.8 \\
\hline $\mathrm{L} \times$ Species and Cult subtotal & 58 & $\ldots$ & $\ldots$ & 17.8 \\
\hline $\mathrm{I} \times \mathrm{G}$ & 1 & 4,949 & $<0.0001$ & 0.6 \\
\hline $\mathrm{I} \times \mathrm{CC}$ & 1 & 927 & 0.0040 & 0.1 \\
\hline $\mathrm{I} \times \mathrm{FF}$ & 1 & 59 & 0.4648 & 0.0 \\
\hline $\mathrm{I} \times$ Cult & 12 & 65 & 0.8517 & 0.1 \\
\hline $\mathrm{MT} \times \mathrm{G}$ & 1 & 2,340 & 0.2156 & 0.3 \\
\hline $\mathrm{MT} \times \mathrm{CC}$ & 1 & 97 & 0.5423 & 0.0 \\
\hline $\mathrm{MT} \times \mathrm{FF}$ & 1 & 128 & 0.4841 & 0.0 \\
\hline MT $\times$ Cult & 12 & 253 & 0.4784 & 0.4 \\
\hline $\mathrm{TT} \times \mathrm{G}$ & 1 & 1,631 & 0.2995 & 0.2 \\
\hline $\mathrm{TT} \times \mathrm{CC}$ & 1 & 1,118 & 0.0391 & 0.1 \\
\hline $\mathrm{TT} \times \mathrm{FF}$ & 1 & 25 & 0.7558 & 0.0 \\
\hline TT $\times$ Cult & 12 & 321 & 0.2587 & 0.5 \\
\hline $\mathrm{IP} \times \mathrm{G}$ & 1 & 3 & 0.9662 & 0.0 \\
\hline $\mathrm{IP} \times \mathrm{CC}$ & 1 & 1,383 & 0.0218 & 0.2 \\
\hline $\mathrm{IP} \times \mathrm{FF}$ & 1 & 611 & 0.1268 & 0.1 \\
\hline
\end{tabular}


$70 \% \mathrm{EtOH}$ for 5 to $10 \mathrm{~s}$, followed by a 5 min soak in a $10 \%$ bleach solution. Sclerotia were then rinsed twice with sterile distilled water and blotted dry on sterile filter paper. Once sufficient growth occurred on the amended PDA, isolates were transferred and maintained on PDA at $5^{\circ} \mathrm{C}$ in total darkness.

In October 1998, 1999, and 2000, the plots were inoculated using the above-mentioned isolates. Inoculum was prepared by placing five 4-week-old, 7-mm-diameter mycelial plugs of each isolate in a 1-liter Erlenmeyer flask of sterilized (autoclaved) millet seed. The flasks were then placed in darkness at $5^{\circ} \mathrm{C}$ for approximately 45 days. The millet seed medium was prepared by combining 250 $\mathrm{ml}$ of seed with $200 \mathrm{ml}$ of water, allowing imbibitions overnight, then autoclaving twice at $121^{\circ} \mathrm{C}$ for $45 \mathrm{~min}$. Flasks were shaken weekly to redistribute the contents and encourage development of the mycelium. Once millet seed appeared to be uniformly covered with mycelium, after about 6 weeks of incubation, the inoculum was spread on sterile paper and air dried in a sterile laminar flow hood at room temperature for 2 days. The inoculum was broadcast in the field at a rate of $7 \mathrm{~g} \mathrm{~m}^{-2}$ using a shaker jar. Inoculum of $T$. phacorrhiza was spread only at the Land O'Lakes site and T. ishikariensis was applied only at Stevens Point and Land O'Lakes because environmental conditions are typically favorable to these organisms only at these sites (14). The plots did not receive fungicide applications 1 month prior to inoculation and for 1 month following snowmelt.

Data collection and statistical analysis. Disease severity (percent) and live ground cover (percent) were visually rated in each plot following snowmelt. Damage was attributed to various snow mold pathogens based on patch appearance and sclerotia $(14,17)$. Damaged turf patches appear as circular, straw-colored turf, with a sunken or matted appearance. Patches caused by $M$. nivale had a pinkish caste to the margins and no sclerotia were present. Patches caused by Typhula spp. had a grayish caste to the margins and sclerotia were present. The Typhula sp. responsible for the patch was identified by examining sclerotia from the patch, because each has a characteristic rind pattern (14). Turfgrass quality and $P$. annua invasion (percent cover) were visually rated in the fall of each year. Symptoms did not develop at the Verona site in 2000; therefore, these data were excluded from all statistical analyses, resulting in five location-year experimental combinations.

Data were analyzed by a linear mixed models analysis using SAS (12). Locations, inoculation, isolates, species, and cultivars were treated as fixed effects and replicates were treated as the only random effect (Table 1). Locations were defined as five seeded experiments and treated as a fixed effect due to the environmental specificity of the pathogens and the limited inferences possible with only 2 years (i.e., limited ability to assume that two consecutive years represent a truly random sample). The isolate main effect was separated into three single-degree-of-freedom contrasts: Microdochium versus Typhula, T. incarnata versus others, and T. ishikariensis versus T. phacorrhiza. The species main effect was separated into three single-degree-of-freedom contrasts (bentgrass versus fescue, creeping versus colonial bentgrasses, and Chewing's versus red fescues), while cultivars were nested within

Table 1. (continued from preceding page)

\begin{tabular}{|c|c|c|c|c|}
\hline Source & df & MS & $P$ value & $\% \mathrm{SS}$ \\
\hline IP $\times$ Cult & 12 & 218 & 0.6141 & 0.3 \\
\hline $\mathrm{I} \times \mathrm{MT} \times \mathrm{G}$ & 1 & 966 & 0.0033 & 0.1 \\
\hline $\mathrm{I} \times \mathrm{MT} \times \mathrm{CC}$ & 1 & 752 & 0.0095 & 0.1 \\
\hline $\mathrm{I} \times \mathrm{MT} \times \mathrm{FF}$ & 1 & 143 & 0.2564 & 0.0 \\
\hline $\mathrm{I} \times \mathrm{MT} \times$ Cult & 12 & 141 & 0.2350 & 0.2 \\
\hline $\mathrm{I} \times \mathrm{TT} \times \mathrm{G}$ & 1 & 3 & 0.8796 & 0.0 \\
\hline $\mathrm{I} \times \mathrm{TT} \times \mathrm{CC}$ & 1 & 2,028 & $<0.0001$ & 0.3 \\
\hline $\mathrm{I} \times \mathrm{TT} \times \mathrm{FF}$ & 1 & 1 & 0.9408 & 0.0 \\
\hline $\mathrm{I} \times \mathrm{TT} \times$ Cult & 12 & 116 & 0.4062 & 0.2 \\
\hline $\mathrm{I} \times \mathrm{IP} \times \mathrm{G}$ & 1 & 91 & 0.3658 & 0.0 \\
\hline $\mathrm{I} \times \mathrm{IP} \times \mathrm{CC}$ & 1 & 1,104 & 0.0017 & 0.1 \\
\hline $\mathrm{I} \times \mathrm{IP} \times \mathrm{FF}$ & 1 & 0 & 0.9916 & 0.0 \\
\hline $\mathrm{I} \times \mathrm{IP} \times$ Cult & 12 & 141 & 0.2344 & 0.2 \\
\hline Host $\times$ Pathogen subtotal & 90 & $\ldots$ & $\ldots$ & 3.5 \\
\hline $\mathrm{L} \times \mathrm{I} \times \mathrm{G}$ & 4 & 1,796 & $<0.0001$ & 0.9 \\
\hline $\mathrm{L} \times \mathrm{I} \times \mathrm{CC}$ & 4 & 1,405 & $<0.0001$ & 0.7 \\
\hline $\mathrm{L} \times \mathrm{I} \times \mathrm{FF}$ & 4 & 49 & 0.7799 & 0.0 \\
\hline $\mathrm{L} \times \mathrm{I} \times$ Cult & 46 & 85 & 0.8665 & 0.5 \\
\hline $\mathrm{L} \times \mathrm{MT} \times \mathrm{G}$ & 4 & 4,589 & 0.0279 & 2.4 \\
\hline $\mathrm{L} \times \mathrm{MT} \times \mathrm{CC}$ & 4 & 1,927 & $<0.0001$ & 1.0 \\
\hline $\mathrm{L} \times \mathrm{MT} \times \mathrm{FF}$ & 4 & 32 & 0.9736 & 0.0 \\
\hline $\mathrm{L} \times \mathrm{MT} \times \mathrm{Cult}$ & 46 & 286 & 0.3170 & 1.7 \\
\hline $\mathrm{L} \times \mathrm{TT} \times \mathrm{G}$ & 3 & 4,809 & 0.0334 & 1.9 \\
\hline $\mathrm{L} \times \mathrm{TT} \times \mathrm{CC}$ & 3 & 777 & 0.0313 & 0.3 \\
\hline $\mathrm{L} \times \mathrm{TT} \times \mathrm{FF}$ & 3 & 197 & 0.5195 & 0.1 \\
\hline $\mathrm{L} \times \mathrm{TT} \times$ Cult & 34 & 452 & 0.0076 & 2.0 \\
\hline $\mathrm{L} \times \mathrm{IP} \times \mathrm{G}$ & 1 & 197 & 0.7167 & 0.0 \\
\hline $\mathrm{L} \times \mathrm{IP} \times \mathrm{CC}$ & 1 & 18 & 0.7957 & 0.0 \\
\hline $\mathrm{L} \times \mathrm{IP} \times \mathrm{FF}$ & 1 & 217 & 0.3625 & 0.0 \\
\hline $\mathrm{L} \times \mathrm{IP} \times$ Cult & 11 & 258 & 0.4560 & 0.4 \\
\hline $\mathrm{L} \times \mathrm{I} \times \mathrm{MT} \times \mathrm{G}$ & 4 & 1,072 & $<0.0001$ & 0.6 \\
\hline $\mathrm{L} \times \mathrm{I} \times \mathrm{MT} \times \mathrm{CC}$ & 4 & 558 & 0.0006 & 0.3 \\
\hline $\mathrm{L} \times \mathrm{I} \times \mathrm{MT} \times \mathrm{FF}$ & 4 & 21 & 0.9425 & 0.0 \\
\hline $\mathrm{L} \times \mathrm{I} \times \mathrm{MT} \times$ Cult & 46 & 62 & 0.9917 & 0.4 \\
\hline $\mathrm{L} \times \mathrm{I} \times \mathrm{TT} \times \mathrm{G}$ & 3 & 1,655 & $<0.0001$ & 0.6 \\
\hline $\mathrm{L} \times \mathrm{I} \times \mathrm{TT} \times \mathrm{CC}$ & 3 & 438 & 0.0084 & 0.2 \\
\hline $\mathrm{L} \times \mathrm{I} \times \mathrm{TT} \times \mathrm{FF}$ & 3 & 69 & 0.5997 & 0.0 \\
\hline $\mathrm{L} \times \mathrm{I} \times \mathrm{TT} \times$ Cult & 34 & 79 & 0.8909 & 0.3 \\
\hline $\mathrm{L} \times \mathrm{I} \times \mathrm{IP} \times \mathrm{G}$ & 1 & 72 & 0.4204 & 0.0 \\
\hline $\mathrm{L} \times \mathrm{I} \times \mathrm{IP} \times \mathrm{CC}$ & 1 & 16 & 0.7022 & 0.0 \\
\hline $\mathrm{L} \times \mathrm{I} \times \mathrm{IP} \times \mathrm{FF}$ & 1 & 56 & 0.4786 & 0.0 \\
\hline $\mathrm{L} \times \mathrm{I} \times \mathrm{IP} \times \mathrm{Cult}$ & 11 & 134 & 0.2818 & 0.2 \\
\hline $\mathrm{L} \times$ Host $\times$ Pathogen & 230 & $\ldots$ & $\ldots$ & 12.4 \\
\hline
\end{tabular}


these four groups. All possible interaction effects were analyzed between all main effects and evaluated using both $P$ values and percent contribution to the overall treatment sum of squares.

\section{Results}

In all, 35 of the 78 statistical comparisons were significant $(P \leq$ 0.05 ), accounting for $57.4 \%$ of the overall treatment variation with 17 treatment effects and $35.2 \%$ with 18 treatment-location effects (Table 1). However, only four treatment effects (inoculated versus noninoculated, Microdochium versus Typhula, bentgrass versus fescue, and creeping versus colonial bentgrass) and two treatmentlocation effects (bentgrass versus fescue and cultivars within groups) accounted individually for more than $5 \%$ of the overall treatment variation. Three groups of contrasts accounted for nearly $75 \%$ of the total treatment variation: species and cultivars $(37.5 \%)$, inoculation and isolates $(18.3 \%)$, and location-species and cultivars $(17.8 \%)$. Bentgrass versus fescues accounted for greater treatment variation than any other single contrast $(22.8 \%)$, followed by creeping versus colonial (12.2\%). There was no difference between the species of fine fescues. Differences between cultivars accounted for only $2.4 \%$ of the overall treatment variation and only $6.4 \%$ of the species and cultivars subtotal.

Although there were numerous significant treatment-location effects, the most biologically significant of these were for species and cultivars. Disease severity ranged from 4 to $91 \%$ depending on location and grass species groups (Table 2). Creeping bentgrass consistently had the most snow mold damage of any grass. Fine fescues had less snow mold damage than either bentgrass species, except in 1999 at Stevens Point, when colonial bentgrass had less damage. Turf at the southernmost location (Verona) had only mild damage in 1999 and none in 2000.

Inoculations had variable effects on snow mold development depending on the fungal species, year, and location (Table 3). The most dramatic snow mold development occurred at Land O'Lakes and Stevens Point in 1999, when approximately 50 to $88 \%$ of the turf was damaged. Disease severity in 2000 was usually about 20 to $50 \%$ less than the amount that occurred for a given pathogen in 1999. The southernmost location, Verona, had relatively little disease damage in 1999 and none in 2000. Disease severity in non- inoculated plots often appeared to be a combination of at least two pathogens. Inoculations for $M$. nivale and $T$. phacorrhiza were ineffective because disease severity in noninoculated plots was similar to disease in inoculated plots. Inoculation enhanced disease development with $T$. ishikariensis in both years at Land O'Lakes and in Stevens Point in 2000. Disease development from T. incarnata was enhanced only in 2000, at both Land O'Lakes and in Stevens Point. Plots inoculated with $T$. ishikariensis had the most damage at Land O'Lakes in both years and in Stevens Point in 2000.

Inoculation with $T$. ishikariensis and $T$. incarnata generally enhanced disease development on both bentgrass species (Table 4). Only $T$. ishikariensis inoculations enhanced disease on fine fescue, and then only at the northernmost location (Land O'Lakes). Inoculations with $T$. phacorrhiza and $M$. nivale had little to no effect on total disease development on any grass species.

$P$. апnиa invasion during the growing season following each winter assessment period was greatest in 1999, especially at Land O'Lakes, where $P$. annua covered 40 to $75 \%$ of the ground area (Table 5). Fine fescues were usually more susceptible to $P$. annua invasion than either of the bentgrasses regardless of location. Averaged across years and locations, none of the grass groups exhibited acceptable mean turfgrass quality (average quality score of 6.0 or higher) toward the end of the growing season (Table 6). One or both of the bentgrass species had acceptable quality during various location-year combinations but fine fescue never displayed acceptable turf quality.

\section{Discussion}

The relatively low amount of snow mold disease on fine fescues compared with bentgrasses indicates that fine fescues may be useful as fairway turf when fungicide use is unacceptable and particularly where conditions favor $M$. nivale or $T$. incarnata rather than T. ishikariensis. Apart from Aamlid et al. (1), no other reports have compared resistance of fine fescues and bentgrasses to snow mold diseases. However, we found that inherent resistance with the fine fescue cultivars tested was insufficient to ensure acceptable protection against damage from snow mold diseases on golf course fairways under all conditions. T. ishikariensis tended to cause the most

Table 2. Mean snow mold damage measured on three cultivar groups evaluated at five Wisconsin locations in 1999 and 2000 (means are over three replicates, four pathogens, two inoculation treatments, and five bentgrass or six fescue cultivars)

\begin{tabular}{lcccccc}
\hline & \multicolumn{5}{c}{ Damage (\%) $^{\mathbf{a}}$} \\
\cline { 2 - 7 } Cultivar group & L1999 & L2000 & S1999 & S2000 & V1999 & Mean \\
\hline Creeping bentgrass $(n=5)$ & 83 & 51 & 91 & 43 & 57 & 17 \\
Colonial bentgrass $(n=5)$ & 64 & 37 & 49 & 21 & 11 & 36 \\
Fine fescues $(n=6)$ & 36 & 11 & 65 & 4 & 4 & 25 \\
LSD $(0.05)^{\mathrm{b}}$ & 6 & 5 & 9 & 4 & 2 & 3 \\
\hline
\end{tabular}

${ }^{a}$ Locations and years: L = Land O' Lakes, S = Steven's Point, V = Verona; 1999 ratings were made on plots established in 1998 and 2000 ratings were made on plots established in 1999 .

${ }^{\mathrm{b}}$ Least significant difference (LSD) value for comparing fine fescue mean with either bentgrass mean or for comparing creeping versus colonial bentgrass means. Divide this value by 1.4 to compare fine fescue mean with the mean of all bentgrass cultivars $(n=10)$.

Table 3. Mean snow mold damage associated with five inoculation treatments applied to creeping bentgrass, colonial bentgrass, Chewing's fescue, and red fescue cultivars evaluated at six locations in 1999 and 2000 (means are over three replicates and 16 cultivars)

\begin{tabular}{|c|c|c|c|c|c|c|}
\hline \multirow[b]{2}{*}{ Inoculation treatment } & \multicolumn{6}{|c|}{ Damage $(\%)^{\mathrm{a}}$} \\
\hline & L1999 & L2000 & S1999 & S2000 & V1999 & V2000 \\
\hline Microdochium nivale & 49 & 8 & 59 & 8 & 9 & 0 \\
\hline Typhula incarnata & 53 & 26 & 76 & 15 & 14 & 0 \\
\hline T. ishikariensis & 88 & 45 & 70 & 26 & NI & NI \\
\hline T. phacorrhiza & 55 & 11 & NI & NI & NI & NI \\
\hline Uninoculated & 51 & 10 & 67 & 6 & 8 & 0 \\
\hline $\operatorname{LSD}(0.05)^{\mathrm{b}}$ & 8 & 7 & 9 & 5 & 3 & 0 \\
\hline $\operatorname{LSD}(0.05)^{\mathrm{c}}$ & 7 & 6 & 8 & 5 & 2 & 0 \\
\hline
\end{tabular}

a Locations and years: L = Land O' Lakes, S = Steven's Point, V = Verona; 1999 ratings were made on plots established in 1998 and 2000 ratings were made on plots established in 1999; NI = not included.

${ }^{\mathrm{b}}$ Least significant difference (LSD) value for comparisons among individual inoculation treatment means.

${ }^{c}$ LSD value for comparing mean of uninoculated control with means of individual inoculation treatments. 
damage of any snow molds on fine fescue, which was not surprising because both $M$. nivale and $T$. incarnata are considered to be less virulent and more facultatively parasitic than $T$. ishikariensis $(10,13)$. Furthermore, the conditions most favorable to $T$. ishikariensis (long snow cover and low temperatures) are most unfavorable to turfgrass. Because T. ishikariensis has the most restricted range of the three pathogens, the most cost-effective breeding efforts may best be directed toward developing resistance for M. nivale and T. incarnata. Moreover, breeding specifically for resistance to $T$. ishikariensis would be complicated by the multiple strains of the pathogen (7). Breeding resistance for one or the other pathogen may improve resistance to all three pathogens, because Tronsmo (18) reported resistance to M. nivale and Typhula spp. was highly correlated in two perennial grasses.

Part of the key to identifying fine fescues with acceptable snow mold resistance may involve cultivars that are better suited to the low heights of cut used on fairways. In our study, fine fescue turf quality the autumn following the establishment year was unacceptable due, in large part, to invasion by $P$. annua resulting in low turf density. The mowing heights used in our study (approximately 1.25

Table 4. Mean snow mold damage measured on three cultivar groups in combination with five inoculation treatments at five locations in 1999 and 2000 (means are over three replicates and five bentgrass or six fescue cultivars)

\begin{tabular}{|c|c|c|c|c|c|c|}
\hline \multirow[b]{2}{*}{ Inoculation treatment, cultivar group } & \multicolumn{6}{|c|}{ Damage $(\%)^{\mathrm{a}}$} \\
\hline & L1999 & L2000 & S1999 & S2000 & V1999 & Mean \\
\hline \multicolumn{7}{|l|}{ Microdochium nivale } \\
\hline Creeping bentgrass $(n=5)$ & 75 & 36 & 84 & 13 & 14 & 44 \\
\hline Colonial bentgrass $(n=5)$ & 46 & 17 & 49 & 9 & 11 & 26 \\
\hline Fine fescues $(n=6)$ & 30 & 4 & 48 & 7 & 2 & 18 \\
\hline \multicolumn{7}{|l|}{ Typhula incarnata } \\
\hline Creeping bentgrass $(n=5)$ & 83 & 74 & 98 & 74 & 24 & 70 \\
\hline Colonial bentgrass $(n=5)$ & 60 & 68 & 48 & 12 & 13 & 40 \\
\hline Fine fescues $(n=6)$ & 21 & 7 & 83 & 16 & 5 & 26 \\
\hline \multicolumn{7}{|l|}{ T. ishikariensis } \\
\hline Creeping bentgrass $(n=5)$ & 98 & 65 & 92 & 75 & NI & 83 \\
\hline Colonial bentgrass $(n=5)$ & 97 & 58 & 56 & 53 & NI & 66 \\
\hline Fine fescues $(n=6)$ & 72 & 37 & 64 & 14 & NI & 47 \\
\hline \multicolumn{7}{|l|}{ T. phacorrhiza } \\
\hline Creeping bentgrass $(n=5)$ & 82 & 46 & NI & NI & NI & 64 \\
\hline Colonial bentgrass $(n=5)$ & 59 & 21 & NI & NI & NI & 40 \\
\hline Fine fescues $(n=6)$ & 30 & 5 & NI & NI & NI & 17 \\
\hline \multicolumn{7}{|l|}{ Uninoculated } \\
\hline Creeping bentgrass $(n=5)$ & 76 & 33 & 92 & 13 & 12 & 45 \\
\hline Colonial bentgrass $(n=5)$ & 57 & 21 & 44 & 8 & 10 & 28 \\
\hline Fine fescues $(n=6)$ & 27 & 4 & 64 & 5 & 4 & 21 \\
\hline $\operatorname{LSD}(0.05)^{\mathrm{b}}$ & 17 & 14 & 22 & 10 & 6 & 15 \\
\hline $\operatorname{LSD}(0.05)^{\mathrm{c}}$ & 9 & 7 & 11 & 5 & 3 & 8 \\
\hline
\end{tabular}

a Locations and years: L = Land O' Lakes, S = Steven's Point, V = Verona; 1999 ratings were made on plots established in 1998 and 2000 ratings were made on plots established in 1999; $\mathrm{NI}=$ not included.

${ }^{\mathrm{b}}$ Least significant difference (LSD) value for comparing fine fescue mean with either bentgrass mean or for comparing creeping versus colonial bentgrass means. Divide this value by 1.4 to compare fine fescue mean with the mean of all bentgrass cultivars $(n=10)$.

${ }^{\mathrm{c}}$ LSD values for the uninoculated treatment means.

Table 5. Mean Роа аппиа ground cover in plots of three cultivar groups evaluated at six locations in 1999 and 2000 (means are over three replicates, four pathogens, two inoculation treatments, and five bentgrass or six fescue cultivars)

\begin{tabular}{|c|c|c|c|c|c|c|c|}
\hline \multirow[b]{2}{*}{ Cultivar group } & \multicolumn{7}{|c|}{ Ground cover $(\%)^{\mathrm{a}}$} \\
\hline & L1999 & L2000 & S1999 & $\mathbf{S 2 0 0 0}$ & V1999 & V2000 & Mean \\
\hline Creeping bentgrass $(n=5)$ & 50 & 7 & 3 & 0 & 0 & 0 & 10 \\
\hline Colonial bentgrass $(n=5)$ & 40 & 3 & 12 & 0 & 3 & 0 & 9 \\
\hline Fine fescues $(n=6)$ & 75 & 30 & 9 & 0 & 7 & 12 & 22 \\
\hline $\operatorname{LSD}(0.05)^{\mathrm{b}}$ & 6 & 7 & 3 & 0 & 2 & 1 & 2 \\
\hline
\end{tabular}

a Locations and years: $\mathrm{L}=$ Land O' Lakes, $\mathrm{S}$ = Steven's Point, $\mathrm{V}$ = Verona; 1999 ratings were made on plots established in 1998 and 2000 ratings were made on plots established in 1999 .

${ }^{b}$ Least significant difference (LSD) value for comparing fine fescue mean with either bentgrass mean or for comparing creeping versus colonial bentgrass means. Divide this value by 1.4 to compare fine fescue mean with the mean of all bentgrass cultivars $(n=10)$.

Table 6. Mean turfgrass quality ( 1 to 9 rating, where $6=$ acceptable and $9=$ best) of three cultivar groups evaluated at six locations in 1999 and 2000 (means are over three replicates, four pathogens, two inoculation treatments, and five bentgrass or six fescue cultivars)

\begin{tabular}{|c|c|c|c|c|c|c|c|}
\hline \multirow[b]{2}{*}{ Cultivar group } & \multicolumn{7}{|c|}{ Quality rating ${ }^{a}$} \\
\hline & L1999 & L2000 & S1999 & $\mathbf{S 2 0 0 0}$ & V1999 & V2000 & Mean \\
\hline Creeping bentgrass $(n=5)$ & 4.3 & 5.7 & 4.7 & 6.7 & 5.1 & 6.6 & 5.5 \\
\hline Colonial bentgrass $(n=5)$ & 4.9 & 6.2 & 3.8 & 6.5 & 5.6 & 5.7 & 5.5 \\
\hline Fine fescues $(n=6)$ & 4.6 & 5.3 & 4.0 & 5.5 & 3.0 & 4.0 & 4.4 \\
\hline $\operatorname{LSD}(0.05)^{\mathrm{b}}$ & 0.2 & 0.8 & 0.3 & 0.3 & 0.1 & 0.3 & 0.2 \\
\hline
\end{tabular}

a Locations and years: L = Land O' Lakes, S = Steven's Point, V = Verona; 1999 ratings were made on plots established in 1998 and 2000 ratings were made on plots established in 1999.

${ }^{\mathrm{b}}$ Least significant difference (LSD) value for comparing fine fescue mean with either bentgrass mean or for comparing creeping versus colonial bentgrass means. Divide this value by 1.4 to compare fine fescue mean with the mean of all bentgrass cultivars $(n=10)$. 
$\mathrm{cm}$ ) were considerably lower than the $5 \mathrm{~cm}$ or more usually recommended for fine fescues, which likely caused severe stress, particularly during the summer months. In contrast, bentgrasses are well adapted to a $1.25-\mathrm{cm}$ height of cut and have better recovery rates due to their growth habit than fine fescue, explaining the lesser degree of $P$. апnua invasion despite having been more severely damaged by snow molds. At the start of our study there were no fine fescue cultivars known to provide acceptable turf quality at a fairway height of cut. A cultivar evaluation was planted in Wiscon$\sin$ in 1998 to test fine fescues at fairway height: when final results were completed in 2002, 2 of the 79 cultivars, both Chewings fescues, averaged a rating of 6 , which was considered minimal for acceptable turf quality (15). Only two cultivars from our present study were included in that test; neither one was considered acceptable. One (Dawson) was a "standard" and provided unacceptable quality even without snow mold pressure. The other was SR 5100 and had an average rating of 5.7, which was statistically similar to the two cultivars with ratings of 6 or above in the 1998 test. In a follow-up trial planted in 2003, 40 of the 53 cultivars provided acceptable quality turf at a fairway height of cut after 4 years, with roughly equal numbers of strong creeping red and Chewing's fescues (16). Additional studies, using newer cultivars known to provide acceptable turf quality, would be helpful to determine the potential for snow mold damage in fungicide-free fine fescue fairway turf.

The superior snow mold resistance of the colonial bentgrass in our study is notable because field data are lacking. Using controlled environments, Chang et al. (7) reported isolate-bentgrass cultivar interactions for $T$. ishikariensis but found no disease differences between creeping and colonial bentgrass. Chang et al. (6) reported that differences in resistance to $T$. incarnata within and between creeping and colonial bentgrasses existed only in plants younger than 15 weeks of age and when inoculum levels were not overwhelming in a controlled-environment situation. Our plants were all at least 16 weeks of age before growth ceased for the year. Even though we found that cultivar differences accounted for less than $3 \%$ of treatment variation for snow mold development, comparisons between golf course fairway and putting green clones show that significant germplasm differences for resistance to $T$. ishikariensis var. ishikariensis exist in creeping bentgrass (19). However, breeding efforts have largely not been directed toward snow mold resistance because fungicides have been readily available. Breeding snow mold resistance into turfgrasses for golf courses is likely to become more important in the future as federal regulations reduce the availability of fungicide usage for turfgrass management. For example, a "stop sale" of quintozene (synonym: pentachloronitrobenzene [PCNB]), one of the most commonly used fungicides for snow mold control in turfgrass systems, was issued by the U.S. Environmental Protection Agency in 2010 on quintozene (synonym: PCNB) and its registration will likely be cancelled (11).

The high rates of $P$. апnua invasion at Land O'Lakes in 1999 compared with 2000 or to other site-locations showcase the tremendous variation between years and locations. Large seed banks and long-term seed viability of $P$. аnnua allow it to be a successful primary colonizer when existing turf swards are killed by snow mold or other agents. Application of dazomet in 1999 likely reduced the amount of $P$. annua seen in 2000 (4). Our data indicate that non-control of snow mold disease can result in a huge ecological shift of turfgrass species within 12 months, because bentgrasses and fine fescue turf contained $40 \%$ or more $P$. annua cover at Land O'Lakes in 1999. Until stable sources of genetic resistance can be found, repeated exposure to snow mold fungi leads to shifts in fairway composition away from bentgrasses and fescues toward $P$. апnиa, at a rate that is highly dependent on host species, the source of snow mold inoculum, and local environmental conditions.
We saw no evidence that $T$. phacorrhiza was a sufficient biological control for any snow mold disease, because plots inoculated with $T$. phacorrhiza had levels of snow mold damage similar to most other plots under all environmental conditions. Previous work has questioned the ecological impact of T. phacorrhiza in Wisconsin (10). The ability of $T$. phacorrhiza to suppress snow mold diseases varies greatly across isolates $(9,21)$. The $T$. phacorrhiza isolate we used may simply have had insufficient ability to suppress other snow mold pathogens.

\section{Acknowledgments}

We thank L. L. Olds Seed Co. and Seed Research of Oregon for seed donations, staff and ownership of Gateway Golf Club and SentryWorld Golf Club and the College of Agricultural and Life Sciences-Agricultural Research Stations for providing space and assistance for the field research, and J. Kerns of the University of Wisconsin-Madison Plant Pathology department for providing useful suggestions and preliminary review of the manuscript.

\section{Literature Cited}

1. Aamlid, T. S., Molteberg, B., Enger, F., Steensohn, A. A., and Susort, A 2006. Evaluation of Agrostis and Festuca varieties for use on Scandinavian golf greens. Bioforsk Rep. 1:1-35.

2. Beard, J. B. 2002. Turf Management for Golf Courses, 2nd ed. Ann Arbor Press, Chelsea, MI

3. Bertrand, A., Castonguay, Y., Cloutier, J., Couture, L., Hsiang, T., Dionne, J., and Laberge, S. 2009. Genetic diversity for pink snow mold resistance in greens-type annual bluegrass. Crop Sci. 49:589-599.

4. Branham, B. E., Hardebeck, G. A., Meyer, J. A., and Reicher, Z. J. 2004. Turfgrass renovation using dazomet to control the Poa апnиa L. soil seed bank. HortScience 39:1763-1767.

5. Burpee, L. L., Mueller, A. E., and Hannusch, D. J. 1987. Suppression of gray snow mold on creeping bentgrass by an isolate of Typhula phacorrhiza. Plant Dis. 71:97-100.

6. Chang, S. W., Chang, T. H., Abler, R. A. B., and Jung, G. 2007. Variation in bentgrass susceptibility to Typhula incarnata and in isolate aggressiveness under controlled environment conditions. Plant Dis. 91:446-452.

7. Chang, S. W., Chang, T. H., Tredway, L., and Jung, G. 2006. Aggressiveness of Typhula ishikariensis isolates to cultivars of bentgrass species (Agrostis spp.) under controlled environment conditions. Plant Dis. 90:951956.

8. Chang, S. W., Scheef, E., Abler, R. A. B., Thompson, S., Johnson, P., and Jung, G. 2006. Distribution of Typhula spp. and Typhula ishikariensis varieties in Wisconsin, Utah, Michigan, and Minnesota. Phytopathology 96:926933.

9. Hsiang, T., and Cook, S. 2001. Effect of Typhula phacorrhiza on winter injury in field trials across Canada. Int. Turfgrass Soc. Res. J. 9:669-673.

10. Hsiang, T., Matsumoto, N., and Millett, S. M. 1999. Biology and management of Typhula snow molds of turfgrass. Plant Dis. 83:788-798.

11. Kerns, J., and Koch, P. 2010. The latest on pentachloronitrobenzene (PCNB). http://www.plantpath.wisc.edu/tdl/PCNB.php

12. Littel, R. C., Milliken, G. A., Stroup, W. W., and Wolfinger, R. D. 1996 SAS system for mixed models. SAS Institute, Cary, NC.

13. Matsumoto, N. 1994. Ecological adaptations of low temperature plant pathogenic fungi to diverse winter climates. Can. J. Plant Pathol. 16:237240.

14. Millett, S. 2000. Distribution, biological and molecular characterization, and aggressiveness of Typhula snow molds of Wisconsin golf courses. Ph.D. dissertation. UMI 9956198.

15. National Turfgrass Evaluation Program. 2003. 1998 National fineleaf fescue test final report No. 03-9. www.ntep.org

16. National Turfgrass Evaluation Program. 2008. 2003 National fineleaf fescue test final report No. 08-9. www.ntep.org

17. Smiley, R. W., Dernoeden, P. H., and Clarke, B. B. 2005. Compendium of Turfgrass Diseases, 3rd ed. American Phytopathological Society, St. Paul, MN.

18. Tronsmo, A. M. 1992. Resistance to snow mould fungi in breeding material of grasses. Norw. J. Agric. Sci. Suppl. 7:35-38.

19. Wang, Z., Casler, M. D., Stier, J. C. Gregos, J. S., and Millett, S. M. 2005. Genotypic variation for snow mold reaction among creeping bentgrass clones. Crop Sci. 45:399-406.

20. Wu, C., and Hsiang, T. 1999. Mycelial growth, sclerotial production and carbon utilization of three Typhula species. Can. J. Bot. 77:312-317.

21. Wu, C., Hsiang, T., Yang, L., and Liu, L. 1998. Efficacy of Typhula phacorrhiza as a biocontrol agent of grey snow mould of creeping bentgrass. Can. J. Bot. 76:1276-1281. 